\title{
IDIOPATHIC RENAL ACIDOSIS IN INFANCY
}

BY

\author{
I. J. CARRÉ, B. S. B. WOOD and W. C. SMALLWOOD \\ From the Children's Hospital, Birmingham
}

(RECEIVED FOR PUBLICATION MARCH 1, 1954)

During recent years idiopathic renal acidosis of infancy has become more widely recognized as a cause of failure to thrive. Common presenting features are anorexia, vomiting and constipation, which usually appear after some months of apparent good health.

In 1935 Lightwood described the clinical syndrome and pathology of nephrocalcinosis in early life. Its association with persistent acidosis was reported in the following year by Butler and his colleagues (Butler, Wilson and Farber, 1936) while Hartmann (1939) and later Stapleton (1949) explained the disorder as an inability of the kidneys to conserve bicarbonate. This renal defect appears to lie in the proximal tubule (Latner and Burnard, 1950); the cause remains obscure (Hutchison and MacDonald, 1951; Doxiadis, 1952; Payne, 1953). In 1952 Payne and Lightwood described the syndrome of idiopathic hypercalcaemia in infants; more recently the suggestion has been made that alkalis may be of aetiological importance in this condition and also that it may be related to infantile renal acidosis.

Although idiopathic renal acidosis in infants may occur in a mild and non-fatal form, it is believed that the majority of severe cases succumb if untreated. Perhaps the most important feature of the disordered renal function is its temporary nature for, after a prolonged course of corrective treatment with alkalis, complete recovery seems to occur.

The study reported here relates to 17 infants with idiopathic renal acidosis diagnosed and treated in the Birmingham Children's Hospital during the five-year period from February, 1948, to February, 1953. Through the kindness of the physicians concerned one or other of us has been able to follow the progress of all 17. The clinical features and treatment of each have been reviewed and are here summarized. The biochemical studies have been re-examined with particular reference to azotaemia and hypercalcaemia. Thirteen patients, in whom treatment with alkali has been discontinued for periods of from four months to four and a half years, have been re-examined to assess long-term prognosis. Further, we have examined this series for possible aetiological factors, paying particular attention to the dietary history and the administration of such household remedies as 'magnesia'.

\section{Diagnostic Criteria}

We have accepted as diagnostic of the disorder the finding of a plasma $\mathrm{CO}_{2}$-combining power of below 40 vol. $\%$ together with a urinary $p \mathrm{H}$ persistently above 6.5 in a fresh specimen.

\section{Clinical Features}

Constipation and vomiting are the commonest and earliest symptoms. Sooner or later they are accompanied by anorexia, fretfulness and loss of weight. The physical findings include wasting, dehydration, hypotonia, palpable faecal masses in the abdomen, unexplained low fever and sighing. In 11 infants the urine was sterile on culture and contained no abnormality of the deposit. In six, white blood cells were present in excessive amounts, but in only two of these were organisms, believed to be pathogenic, cultured from catheter specimens. These observations, together with the patient's sex and the age of onset of the disorder, are summarized in Table 1. The bones of six were radiographed and showed no rickets or other abnormality. Nephrocalcinosis was looked for in all but was demonstrated in only one case in this series. This infant failed to respond to alkali and died three days after starting that treatment. The renal calcification was demonstrated histologically. During the five-year period under review eight other children in hospital were diagnosed as having nephrocalcinosis, one by radiography and seven at necropsy. None of these had clinical features suggestive of infantile renal acidosis.

\section{Chemistry of the Blood, Chromatographic Analysis of the Urine and Haematology}

While the first cases to be recognized in the hospital were investigated fairly fully, familiarity 
TABLE 1

CLINICAL FINDINGS

\begin{tabular}{|c|c|c|c|c|c|c|c|c|c|c|c|c|c|c|c|c|c|c|c|c|}
\hline \multirow[b]{2}{*}{$\begin{array}{l}\dot{8} \\
\dot{z} \\
\dot{J}\end{array}$} & \multicolumn{3}{|c|}{ Age in Months at } & \multicolumn{7}{|c|}{$\begin{array}{l}\text { Symptoms in Order } \\
\text { of Appearance }\end{array}$} & \multicolumn{4}{|c|}{ Signs } & \multicolumn{6}{|c|}{$\begin{array}{l}\text { Blood and Urine Values Shortly before } \\
\text { Starting Treatment }\end{array}$} \\
\hline & 岕 & 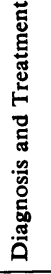 & 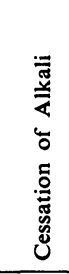 & ל. & 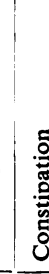 & 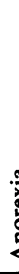 & & & 怘 & 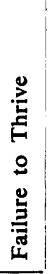 & 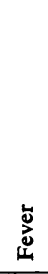 & 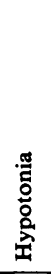 & 量 & 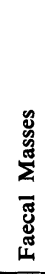 & 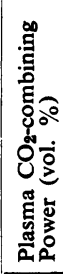 & 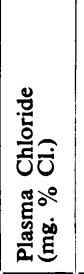 & 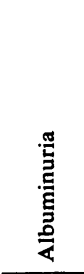 & $\begin{array}{l}\frac{1}{2} \\
: \\
.5 \\
5\end{array}$ & 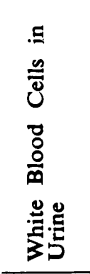 & 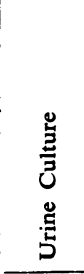 \\
\hline $\begin{array}{l}1 \\
2 \\
3\end{array}$ & $\begin{array}{l}4 \\
7 \\
3\end{array}$ & $\begin{array}{r}11 \\
11 \\
6\end{array}$ & $\begin{array}{l}14 \\
44 \\
30\end{array}$ & 3 & 1 & & & $\begin{array}{l}5 \\
5 \\
4\end{array}$ & $\begin{array}{l}6 \\
5 \\
3\end{array}$ & $\begin{array}{l}4 \\
3 \\
6\end{array}$ & $\begin{array}{l}+ \\
+ \\
+\end{array}$ & $\begin{array}{l}0 \\
+ \\
+\end{array}$ & $\begin{array}{l}+ \\
+ \\
+\end{array}$ & $\begin{array}{l}0 \\
0 \\
+ \\
+\end{array}$ & $\begin{array}{l}21 \\
23 \\
32\end{array}$ & \begin{tabular}{|l|}
435 \\
$384 \cdot 6$ \\
384
\end{tabular} & $\begin{array}{l}\text { Trace } \\
\text { Trace } \\
\text { Light }\end{array}$ & $\begin{array}{l}7.0 \\
7.5 \\
7.6\end{array}$ & $\stackrel{+}{\stackrel{+}{\mathrm{Nil}}}++$ & $\begin{array}{l}\text { Neg. } \\
\text { Neg. } \\
\text { Proteu }\end{array}$ \\
\hline $\begin{array}{l}4 \\
5 \\
6 \\
7\end{array}$ & $\begin{array}{l}7 \\
3 \\
5 \\
7\end{array}$ & $\begin{array}{r}11 \\
7 \\
7 \\
8\end{array}$ & $\begin{array}{l}23 \\
16 \\
23 \\
\text { no } \\
\text { alka }\end{array}$ & $\begin{array}{l}1 \\
2 \\
6\end{array}$ & $\begin{array}{l}3 \\
1 \\
5\end{array}$ & & & $\frac{6}{3}$ & $\frac{5}{1}$ & $\begin{array}{r}4 \\
5 \\
3\end{array}$ & $\begin{array}{l}0 \\
+ \\
+ \\
0\end{array}$ & $\begin{array}{l}+ \\
+ \\
0 \\
0\end{array}$ & $\begin{array}{c}0 \\
0 \\
0 \\
+\end{array}$ & $\begin{array}{l}0 \\
+ \\
+ \\
0\end{array}$ & $\begin{array}{l}24 \\
24 \\
33 \\
37\end{array}$ & \begin{tabular}{|l|}
$449 \cdot 1$ \\
393 \\
409 \\
394
\end{tabular} & $\begin{array}{l}\text { cloud } \\
\text { Trace } \\
\text { Trace } \\
\text { Nil } \\
\text { Haze }\end{array}$ & $\begin{array}{l}7 \cdot 5 \\
6 \cdot 5 \\
7 \cdot 1 \\
7 \cdot 0\end{array}$ & $\begin{array}{l}\mathrm{Nil} \\
++ \\
\text { Nil } \\
\text { Nil }\end{array}$ & $\begin{array}{l}\text { Neg. } \\
\text { Neg. } \\
\text { Neg. } \\
\text { Neg. }\end{array}$ \\
\hline 8 & $4 \frac{1}{2}$ & 6 & 26 & 2 & 1 & & & 6 & 5 & 4 & + & 0 & + & + & 21 & $518 \cdot 5$ & Light & $7 \cdot 5$ & +++ & Neg. \\
\hline $\begin{array}{r}9 \\
10\end{array}$ & 5 & $\begin{array}{l}6 \frac{1}{2} \\
5 \frac{1}{2}\end{array}$ & $24 \frac{1}{15}$ & 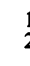 & 3 & & & $\frac{4}{5}$ & $\begin{array}{l}6 \\
6\end{array}$ & 2 & $\begin{array}{l}\mathbf{0} \\
\mathbf{0}\end{array}$ & $\begin{array}{c}0 \\
+\end{array}$ & $\begin{array}{l}0 \\
0\end{array}$ & $\stackrel{0}{+}$ & $\begin{array}{l}36 \\
33\end{array}$ & $\begin{array}{l}401 \cdot 6 \\
392 \cdot 4\end{array}$ & $\begin{array}{l}\text { coud } \\
\text { Night } \\
\text { Light }\end{array}$ & $\begin{array}{l}7 \cdot 5 \\
7 \cdot 0\end{array}$ & $\begin{array}{l}\text { Nil } \\
+++\end{array}$ & $\begin{array}{l}\text { Neg. } \\
\text { Neg. }\end{array}$ \\
\hline $\begin{array}{l}11 \\
12 \\
13 \\
14 \\
15\end{array}$ & $\begin{array}{l}4 \frac{1}{2} \\
62 \\
12 \\
9 \frac{1}{2} \\
4 \frac{1}{2}\end{array}$ & $\begin{array}{r}7 \\
8 \\
14 \\
11 \\
7\end{array}$ & $\begin{array}{c}17 \\
16 \\
24 \\
19 \\
\text { Died }\end{array}$ & $\begin{array}{l}1 \\
1 \\
6 \\
3 \\
2\end{array}$ & 3 & & & $\begin{array}{l}4 \\
4 \\
4 \\
6 \\
\end{array}$ & $\begin{array}{l}\frac{6}{1} \\
1 \\
4\end{array}$ & $\begin{array}{l}3 \\
2 \\
5 \\
5 \\
1\end{array}$ & $\begin{array}{c}0 \\
0 \\
0 \\
0 \\
+\end{array}$ & $\begin{array}{l}0 \\
0 \\
+ \\
+ \\
+\end{array}$ & $\begin{array}{l}0 \\
0 \\
+ \\
0 \\
+\end{array}$ & $\begin{array}{l}0 \\
+ \\
0 \\
0 \\
0\end{array}$ & $\begin{array}{l}29 \\
25 \\
32 \\
39 \\
30\end{array}$ & \begin{tabular}{|l|}
422 \\
$440 \cdot 2$ \\
$381 \cdot 4$ \\
$396 \cdot 6$ \\
$440 \cdot 5$ \\
\end{tabular} & $\begin{array}{l}\text { cloud } \\
\text { Trace } \\
\text { Haze } \\
\text { Haze } \\
\text { Trace } \\
\text { Light } \\
\text { cloud }\end{array}$ & $\begin{array}{l}7.3 \\
7 \cdot 0 \\
7 \cdot 0 \\
7.0 \\
7 \cdot 5\end{array}$ & $\begin{array}{l}\mathrm{Nil} \\
\mathrm{Nil} \\
\mathrm{Nil} \\
\mathrm{Nil} \\
+++\end{array}$ & $\begin{array}{l}\text { Neg. } \\
\text { Neg. } \\
\text { Neg. } \\
\text { Neg. } \\
\text { Bact. }\end{array}$ \\
\hline 16 & 6 & 8 & Still & 1 & - & & & & - & 2 & $\mathbf{0}$ & + & $\mathbf{0}$ & + & 25 & $432 \cdot 5$ & Light & $7 \cdot 0$ & Nil & Neg. \\
\hline 17 & 7 & $9 \frac{1}{2}$ & $\begin{array}{l}\text { treat } \\
\text { ment }\end{array}$ & 2 & 1 & & & & 6 & 4 & + & + & 0 & 0 & 35 & $394 \cdot 2$ & Haze & 6.9 & Nil & Neg. \\
\hline
\end{tabular}

with the disorder in later years appears to have resulted in fewer and less detailed biochemical studies. The results shown in Table 2 indicate that investigation was often incomplete.

While seven had a raised blood urea level on admission, in six this fell to normal within a week

TABLE 2

BIOCHEMICAL RESULTS

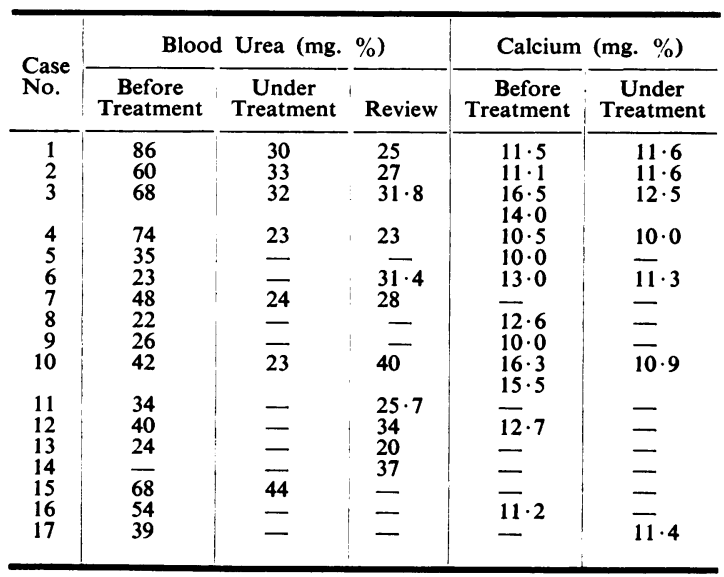

of beginning treatment. Figures for serum calcium were high in five and with treatment with alkalis rapidly became normal in two. In two the investigation was not repeated. Acidosis, hypercalcaemia and definite azotaemia were present together in the fifth case (No. 3); whereas acidosis was rapidly corrected with alkali the azotaemia persisted for 10 months and hypercalcaemia for three and a half months. The urines from four patients were examined by Dr. H. Bickel by paper chromatography (Bickel and Hickmans, 1952) before treatment was begun and of these only one showed increased excretion of the amino-acids taurine, tyrosine, phenylalanine, cystine and lysine. Urinary chromatograms for sugar and amino-acids from these four patients while under treatment and from four others in this series, also under treatment, were normal for the age.

Not all the children in this series were investigated haematologically but in nine, anaemia with haemoglobin values of from 50 to $70 \%$ (average $60 \%$ Haldane new standard) was found during the course of treatment with alkali (Table 3). In seven, the drop in haemoglobin is known to have occurred during such treatment and to have taken an average 
TABLE 3

HAEMATOLOGICAL RESULTS

\begin{tabular}{|c|c|c|c|c|c|c|c|}
\hline \multirow{3}{*}{$\begin{array}{c}\text { Case } \\
\text { No. }\end{array}$} & \multirow{3}{*}{$\begin{array}{c}\text { Age in Months when } \\
\text { Treatment with Alkali } \\
\text { Begun }\end{array}$} & \multicolumn{4}{|c|}{ Values for Haemoglobin and Colour Index } & \multirow{3}{*}{$\begin{array}{l}\text { Duration of Treatment in } \\
\text { Months before Occurrence } \\
\text { of Anaemia as Noted in } \\
\text { Previous Column }\end{array}$} & \multirow{3}{*}{$\begin{array}{l}\text { Improvement on } \\
\text { Oral Iron }\end{array}$} \\
\hline & & \multicolumn{2}{|c|}{$\begin{array}{c}\text { Before Treatment with } \\
\text { Alkali }\end{array}$} & \multicolumn{2}{|c|}{ During Treatment with } & & \\
\hline & & Hb (\%) & C.I. & $\mathrm{Hb}(\%)$ & C.I. & & \\
\hline 2 & 11 & 100 & - & 65 & 0.83 & 4 & $\begin{array}{c}\text { Rapid } \\
\text { (also transfused) }\end{array}$ \\
\hline $\begin{array}{r}4 \\
8 \\
9 \\
11 \\
12 \\
13 \\
16 \\
17\end{array}$ & $\begin{array}{r}11 \\
6 \\
6 \\
7 \\
8 \\
14 \\
8 \\
9\end{array}$ & $\begin{array}{l}65 \\
90 \\
90 \\
85 \\
80 \\
95 \\
-\end{array}$ & $\begin{array}{l}0.82 \\
0.88 \\
-\overline{0.92} \\
0.82 \\
0.73 \\
0.91 \\
-\end{array}$ & $\begin{array}{l}50 \\
55 \\
65 \\
60 \\
50 \\
65 \\
60 \\
70\end{array}$ & $\begin{array}{l}0.62 \\
- \\
0 \cdot 86 \\
0 \cdot 78 \\
0 \cdot 59 \\
0 \cdot 66 \\
0 \cdot 72\end{array}$ & $\begin{array}{l}6 \\
5 \\
4 \\
5 \\
4 \frac{1}{2} \\
1 \frac{1}{2} \\
1 \frac{1}{2} \\
2\end{array}$ & $\begin{array}{l}\text { Rapid } \\
\text { Rapid } \\
\text { None Given } \\
\text { Rapid } \\
\text { Rapid } \\
\text { Rapid } \\
\text { Slow } \\
\text { Slow }\end{array}$ \\
\hline
\end{tabular}

of nearly four months to develop. It is not explained by relief of any dehydration that was present on admission. The average daily dose of sodium citrate given to children in this group was $10 \mathrm{~g}$. and the ages of the affected children ranged from 6 to 14 months at the beginning of treatment.

The anaemia in four cases was moderately hypochromic as judged by the colour indices (average 0.65 ), while in three the average colour index was 0.82 and in two others red cell counts were not made. Eight, including one who was transfused, were treated with oral iron with rapid recovery in six and slow recovery in two.

\section{Treatment with Alkali}

In this series of 17 children, all but one (Case 7) were treated with alkali given as a sodium citrate-citric acid mixture or as sodium citrate alone. Potassium salts were not used. In each child an attempt was made to find the dose which would maintain the plasma $\mathrm{CO}_{2}$-combining power at a level just above $45 \mathrm{vol}$. \%. At the beginning of treatment this was usually achieved with a daily dose of 3 or $4 \mathrm{~g}$. of alkali and was accompanied by relief of symptoms and gain in weight. This improvement was seldom maintained for long and after a few days or weeks symptoms returned, weight was lost and figures for $\mathrm{CO}_{2}$-combining power fell, often to the original level. When at this stage the dose of alkali was increased, improvement in symptoms and blood chemistry again followed and a number of such increases in dosage were usually necessary before a sustained satisfactory therapeutic response was achieved. In a minority each increase in dosage of alkali was followed by brief and mild diarrhoea and in one child (Case 6) by a small elevation of temperature. To attain both normal blood chemistry and relief of symptoms relatively large doses of alkali were usually required. Some of these features are well illustrated by Case 6 (Fig. 1). Because the dosage of alkali was largely regulated by estimations of blood $\mathrm{CO}_{2}$-combining power and because specimens of blood for analysis were collected routinely at widely different hours of the day, the possibility of wide fluctuations in alkali reserve over a 24-hour period was considered and investigated. Two infants, each on eight-hourly alkali, had blood samples collected at hourly intervals for 10 hours. No significant fluctuation in $\mathrm{CO}_{2}$-combining power was demonstrated. The average daily dose was about $10 \mathrm{~g}$. sodium citrate (range 3 to $20 \mathrm{~g}$.) given in three or four divided doses. Once on the full dose appropriate to the particular child progress usually became fairly smooth, although in six the course showed marked fluctuation in terms of weight gain or loss and blood $\mathrm{CO}_{2}$-combining power levels.

One difficulty experienced with six children in this series (Cases 3, 6, 8, 11, 12 and 17) was the development of alkalosis with apathy, anorexia, fever, diarrhoea and plasma $\mathrm{CO}_{2}$-combining power of $70 \mathrm{vol} . \%$ or over; this occurred in infants who previously had acidosis, when the daily dose of sodium citrate was increased by as little as $2 \mathrm{~g}$. Return to the former dosage was usually followed promptly by reversion to the earlier mildly acidotic level. They have progressed satisfactorily on the smaller dose of alkali.

Special methods of feeding were not employed in this group. One infant (Case 4) received on admission an intravenous infusion for dehydration. Another (Case 2) was transfused for anaemia. Many received courses of chemotherapy for intercurrent infection.

\section{Follow-up of Treated Cases}

The 13 children no longer under treatment with alkali have been re-examined, their blood and urine 


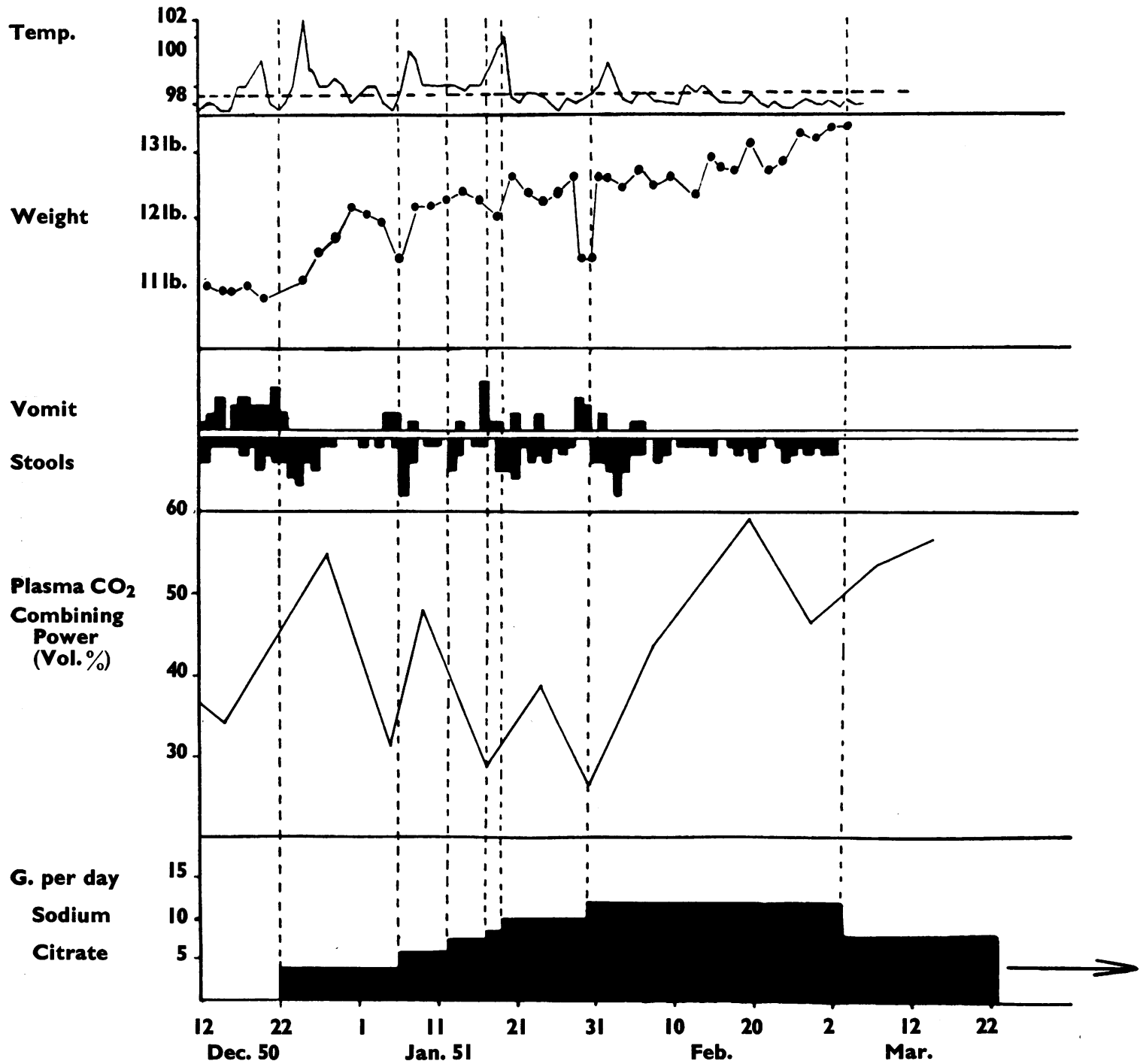

Fig. 1.-Case 6: Clinical and biochemical data during early months of treatment showing the effect of increasingly large doses of alkali.

specimens analysed and their mothers re-interrogated. All have thrived. Height is now almost normal for the age and although as a group their weights still tend to be below average, the discrepancy is much less than before treatment (Table 4). They show no evidence of increased susceptibility to infection, appetite is normal, and although two remain constipated the others have daily bowel actions and pass soft stools. Their blood pressures are normal and radiologically there is no evidence of either rickets or nephrocalcinosis.

The infant (Case 7) who received no alkali or other specific treatment and survived appears to have recovered normal renal function. We regard the disorder in this infant as having been mild.

The blood chemistry, including values for $\mathrm{CO}_{2}$-combining power, chloride, non-protein nitrogen, alkaline phosphatase, sodium, potassium and total protein, is normal in each. Their urines contain no albumin, are clear on microscopy with a $p \mathrm{H}$ below 6.0 in all but one (Case 4, $p \mathrm{H} \mathrm{6.8).}$ This child is also below average weight ( $89 \%$ ) but shows no other abnormality. Chromatograms of the urine made by Dr. H. Bickel show the normal amino-acid patterns for the age in all, while in two 
TABLE 4.

FOLLOW-UP OF TREATED CASES

\begin{tabular}{|c|c|c|c|c|c|c|c|c|}
\hline \multirow[b]{2}{*}{$\begin{array}{l}\text { Case } \\
\text { No. }\end{array}$} & \multicolumn{2}{|c|}{ Age in Months } & \multirow{2}{*}{$\begin{array}{c}\% \text { of Expected } \\
\text { Weight } \\
\text { Before } \\
\text { Treatment }\end{array}$} & \multirow{2}{*}{$\begin{array}{l}\text { Duration of } \\
\text { Treatment } \\
\text { (Months) }\end{array}$} & \multicolumn{4}{|c|}{ Review } \\
\hline & At Onset & At $\underset{\text { Treatment }}{\text { Beginning of }}$ & & & $\begin{array}{l}\text { Age in } \\
\text { Months }\end{array}$ & $\begin{array}{l}\text { Time in Months } \\
\text { since Treatment } \\
\text { Discontinued }\end{array}$ & $\begin{array}{c}\% \text { of } \\
\text { Expected } \\
\text { Weight }\end{array}$ & $\begin{array}{c}\% \text { of } \\
\text { Expected } \\
\text { Height }\end{array}$ \\
\hline $\begin{array}{r}1 \\
2 \\
3 \\
4 \\
5 \\
6 \\
7 \\
8 \\
10 \\
11 \\
12 \\
13 \\
14\end{array}$ & $\begin{array}{c}4 \\
7 \\
3 \\
7 \\
3 \\
5 \\
7 \\
4 \frac{1}{2} \\
4 \frac{1}{2} \\
4 \frac{1}{2} \\
6 \\
12 \\
9 \frac{1}{2}\end{array}$ & $\begin{array}{r}11 \\
11 \\
6 \\
11 \\
7 \\
7 \\
8 \\
6 \\
5 \frac{1}{2} \\
7 \\
8 \\
14 \\
11\end{array}$ & $\begin{array}{l}71 \\
77 \\
54 \\
77 \\
76 \\
73 \\
74 \\
78 \\
87 \\
69 \\
77 \\
74 \\
75\end{array}$ & $\begin{array}{c}3 \\
33 \\
24 \\
12 \\
9 \\
16 \\
\text { nil } \\
20 \\
8 \frac{1}{2} \\
10 \\
8 \\
10 \\
8\end{array}$ & $\begin{array}{l}68 \\
51 \\
45 \\
39 \\
35 \\
32 \\
32 \\
31 \\
27 \\
21 \\
22 \\
31 \\
28\end{array}$ & $\begin{array}{r}54 \\
7 \\
15 \\
16 \\
19 \\
9 \\
5 \\
13 \\
4 \\
6 \\
7 \\
9\end{array}$ & $\begin{array}{r}93 \\
82 \\
100 \\
89 \\
117 \\
80 \\
84 \\
87 \\
91 \\
97 \\
93 \\
88 \\
93\end{array}$ & $\begin{array}{r}99 \\
93 \\
97 \\
98 \\
104 \\
94 \\
95 \\
93 \\
96 \\
? \\
94 \\
100 \\
100\end{array}$ \\
\hline$\overline{\text { Average }}$ & 6 & $8 \frac{1}{2}$ & 74 & $12 \frac{1}{2}$ & - & - & 92 & 97 \\
\hline
\end{tabular}

(Cases 10 and 14) traces of glucose, up to $15 \mathrm{mg} . \%$, have been demonstrated.

\section{Possible Aetiological Nephrotoxic Factors}

The early histories of the children in this series were reviewed by further questioning the mothers of the 16 survivors. The antenatal histories, the administration of vitamins to the mother and child,

\section{TABLE 5}

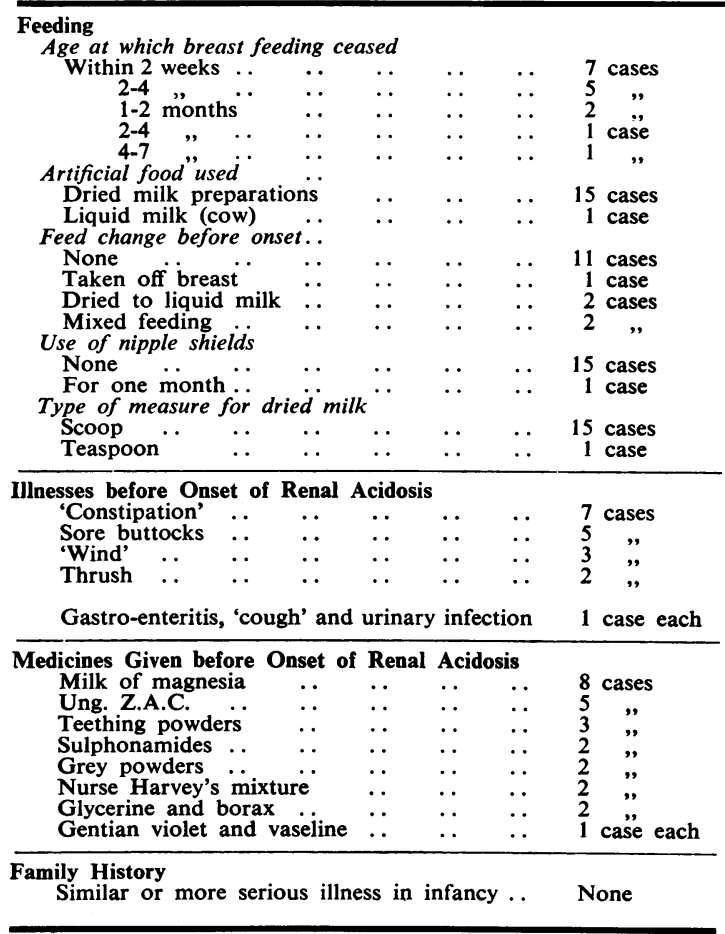

and the birth weights of those subsequently affected and their early post-natal progress showed no significant deviation from the normal. The family histories, methods of feeding employed, illnesses and 'medicines' used before the apparent onset of renal acidosis are listed in Table 5. In view of Creery's (1953) suggestion that the use of 'magnesia' or similar alkali might be an aetiological factor in idiopathic hypercalcaemia, this was made the subject of special enquiry. The results are recorded in Table 6. Of the eight who received 'magnesia' regularly, it seems to us probable that in three at least (Cases 2, 4 and 6) the disordered renal function was present and causing symptoms before the preparation was first used. The figures for blood calcium and urea levels do not appear to bear any relationship to the giving of 'magnesia'.

One infant (Case 3) in this series differed from the others enough to warrant special mention. Azotaemia and hypercalcaemia accompanied the acidosis. Urine specimens contained a light cloud of albumin, an excess of white blood cells, and on culture a pure growth of $B$. proteus was obtained. The urinary infection cleared on treatment with streptomycin but when acidosis persisted treatment with sodium citrate was started. Only $3 \mathrm{~g}$. daily was required to maintain the blood $\mathrm{CO}_{2}$-combining power at a level above $45 \mathrm{vol} . \%$; larger doses produced alkalosis. Alkali was given for 24 months and during this time he made gradual but satisfactory progress. However, blood urea values did not become normal until after 10 months, while normal calcium levels were not recorded until after three and a half months of treatment. When reviewed 12 months after stopping treatment this child appeared well clinically. Blood and urine specimens showed no biochemical abnormality. 
TABLE 6.

ADMINISTRATION OF 'MAGNESIA'

\begin{tabular}{|c|c|c|c|c|c|c|c|}
\hline \multirow{3}{*}{ Case No. } & \multirow{3}{*}{$\begin{array}{l}\text { Age of Onset } \\
\text { of Disease } \\
\text { (Months) }\end{array}$} & \multirow{2}{*}{\multicolumn{2}{|c|}{$\begin{array}{l}\text { Age in Months } \\
\text { Magnesia Given }\end{array}$}} & \multirow{3}{*}{ Dosage } & \multirow{3}{*}{$\begin{array}{c}\text { Reason for } \\
\text { Administration }\end{array}$} & \multicolumn{2}{|c|}{ Blood Chemistry on Admission } \\
\hline & & & & & & \multirow{2}{*}{$\begin{array}{c}\text { Serum Calcium } \\
\text { (mg. \%) }\end{array}$} & \multirow{2}{*}{$\begin{array}{c}\text { Blood Urea } \\
\text { (mg. \%) }\end{array}$} \\
\hline & & From & To & & & & \\
\hline $\begin{array}{l}1 \\
3\end{array}$ & $\begin{array}{l}4 \\
3\end{array}$ & - & - & $\begin{array}{c}\text { Cases with no magnesia admi } \\
-\end{array}$ & - & $\begin{array}{l}11 \cdot 5 \\
16 \cdot 5 \\
14 \cdot 0\end{array}$ & $\begin{array}{l}86 \\
68\end{array}$ \\
\hline $\begin{array}{r}7 \\
16\end{array}$ & $\begin{array}{l}7 \\
6\end{array}$ & - & - & - & - & $\overline{11 \cdot 2}$ & $\begin{array}{l}48 \\
54\end{array}$ \\
\hline $\begin{array}{r}5 \\
8 \\
11 \\
17\end{array}$ & $\begin{array}{l}3 \\
4 \frac{1}{2} \\
4 \frac{1}{2} \\
7\end{array}$ & $\overline{1}$ & $\begin{array}{l}5 \\
-\end{array}$ & $\begin{array}{l}\text { Cases receiving occasional or } \\
\text { Occasional dose only } \\
\frac{1}{2} \text { teaspoon occasionally } \\
\text { Occasional dose only } \\
\text { Occasional dose only }\end{array}$ & $\begin{array}{l}\text { radic administrat } \\
\text { None given } \\
\text { Constipation } \\
\text { Wind } \\
\text { None given }\end{array}$ & $\begin{array}{r}10 \cdot 0 \\
12 \cdot 6 \\
-\end{array}$ & $\begin{array}{l}35 \\
22 \\
34 \\
39\end{array}$ \\
\hline $\begin{array}{r}2 \\
4 \\
6 \\
9 \\
10\end{array}$ & $\begin{array}{l}7 \\
7 \\
5 \\
5 \\
4 \frac{1}{2}\end{array}$ & $\begin{array}{l}5 \\
6 \frac{1}{2} \\
4 \\
3 \\
1\end{array}$ & $\begin{array}{l}8 \\
8 \\
7 \\
5 \\
5\end{array}$ & $\begin{array}{l}\text { Cases receiving regular admin } \\
\text { In moderate dosage } \\
3 \text { teaspoons per week } \\
2 \text {," } \\
\frac{1}{2} \text { teaspoon twice daily } \\
\frac{1}{2} \text { teaspoon twice weekly } \\
1 \text { teaspoon daily }\end{array}$ & $\begin{array}{l}\text { tration: } \\
\text { Constipation } \\
\text { ", } \\
\text { Wind } \\
\text { Constipation }\end{array}$ & $\begin{array}{l}11 \cdot 1 \\
10 \cdot 5 \\
13 \cdot 0 \\
10 \cdot 0 \\
16 \cdot 3 \\
16 \cdot 5\end{array}$ & $\begin{array}{l}60 \\
74 \\
23 \\
26 \\
42\end{array}$ \\
\hline 14 & $9 \frac{1}{2}$ & $2 \frac{1}{2}$ & 10 & 1 teaspoon daily & Wind & 10 & - \\
\hline $\begin{array}{l}12 \\
13\end{array}$ & $\begin{array}{r}6 \\
12\end{array}$ & $\begin{array}{l}3 \\
1\end{array}$ & $\begin{array}{r}7 \\
11\end{array}$ & $\begin{array}{l}\text { In heavy dosage } \\
1 \text { teaspoon five times daily } \\
1 \text { teaspoon three times daily }\end{array}$ & $\begin{array}{c}\text { Wind } \\
\text {," }\end{array}$ & $\stackrel{12 \cdot 7}{-}$ & $\begin{array}{l}40 \\
24\end{array}$ \\
\hline
\end{tabular}

\section{Discussion}

The underlying defect in this disorder, namely inability of the kidneys to conserve bicarbonate, is reflected in the acidotic state of the blood and the passage of urine of high, or relatively high, $p \mathrm{H}$. In the group of cases here described the diagnostic criteria have been the passage of urine specimens with a $p \mathrm{H}$ consistently 6.5 or above and a plasma $\mathrm{CO}_{2}$-combining power of less than $40 \mathrm{vol}$. $\%$. Doxiadis (1952) has recently suggested that the diagnosis of infantile renal acidosis should be based not so much on absolute values for blood and urine as on the discrepancy between the figures for these two fluids. We believe that the criteria for diagnosis in the series described here has excluded all doubtful cases and it is probable that most of those included represent relatively severe examples of the disorder.

This review of 17 infants has confirmed the earlier clinical descriptions of the disorder. Nephrocalcinosis was observed in only one case in this series. This child died early in treatment. It was not demonstrated in any others, either during the course of their illness, or when reviewed later. These observations support the general opinion that with adequate and early treatment of infantile renal acidosis the development of nephrocalcinosis is probably prevented.

Review of the blood electrolytes (Table 2) in this series lends some support to the suggestion made by Lightwood and Stapleton (1953) that infantile renal acidosis and infantile hypercalcaemia are related conditions. If that is so then it is possible to visualize within this group of cases differing patterns of blood chemistry in which, from case to case, the emphasis is shifted between acidosis, hypercalcaemia, azotaemia or other abnormality.

Latner and Burnard (1950) have brought forward evidence which suggests that in infantile renal acidosis the disordered function is largely that of the proximal tubule. We have considered a possible relationship with Lignac-Fanconi's disease, a condition in which persistent acidosis may be associated with the passage of neutral or alkaline urine and one in which the proximal tubule is also considered to be disordered. Both diseases have many clinical features in common, but in Lignac-Fanconi's disease two important findings are the heavy urinary excretion of glucose and of about 20 amino-acids, especially in the untreated acute infantile variety of the disorder (Bickel, Smallwood, Smellie and Hickmans, 1952). The present study of infantile renal acidosis included examination of the urine by paper chromatography for evidence of amino-aciduria and glycosuria. These examinations were carried out on 14 untreated patients, four of them in the present series, on eight cases while under treatment with alkali and on 13 followed up after treatment had been discontinued. In the single deviation from the normal, the pattern of amino-aciduria was suggestive of liver disease and not at all typical of LignacFanconi disease. The trace of sugar demonstrated by paper chromatography in the urines of two 
children who had ceased treatment are findings noted occasionally in healthy infants. It may be concluded that amino-aciduria and glycosuria are not features of infantile renal acidosis and that they are important in differentiating the disorder from untreated Lignac-Fanconi disease.

In the series described here the long-term results of treatment with alkali in doses sufficient to achieve and maintain normal blood chemistry do not appear any better than those reported by Doxiadis who used smaller doses aimed only at giving symptomatic relief. Mention has already been made of the occurrence of alkalosis in some of the infants in our series. These developments, although none of them fatal, and the knowledge that impaired renal function accompanies alkalosis, suggest that it is probably better to treat with moderate doses of alkali and achieve gradual relief of symptoms rather than to attempt early and complete biochemical control with larger doses. The patients did not receive any supplement of potassium.

Azotaemia, noted in seven cases at the first examination, was relieved so rapidly in six that its origin in dehydration appears probable.

While the beneficial, probably life-saving, effects of alkali therapy are now well known, little has been published about remote prognosis and the child's development after treatment has been discontinued. Doxiadis in 1952 mentioned two previously published cases of infantile renal acidosis which appeared to have gone on to complete recovery; one reported by Kelsey, Reinhart and Fishel (1950) the other originally reported by Stapleton (1949) and reviewed by Doxiadis three years after treatment ceased. To these Doxiadis added a further seven followed up for from 10 to 21 months after alkali therapy had been discontinued; all were apparently well.

The present review includes infants in whom the interval between stopping treatment and review varied from four months to four and a half years. They now appear well and show no biochemical abnormality. Physical development has been satisfactory although the average weight for the group is still below the normal average. These observations confirm the suggestion that the condition is a self-limiting process and that recovery, probably complete, is likely to follow if these infants can be tided over the phase of disordered renal function.

The finding of anaemia in association with infantile renal acidosis does not appear to have been noted in previous reports. It is regretted that the haematological examinations made in this series of cases are so few and incomplete. The available data indicate that anaemia often develops after some months of treatment with alkali, that it is not due to relief of dehydration, that it is often hypochromic and that it is relieved, usually quite rapidly, by treatment with iron. Anaemia seems to have developed particularly in those who received large doses of alkali and, since alkalinization of the upper alimentary tract is known to restrict the absorption of iron (Kellogg and Mettier, 1936; Mettier and Minot, 1931), this may be a causal factor in our cases. Other aetiological factors are the rapid growth under treatment of a previously marasmic anorexic infant and the blood loss resulting from repeated venepunctures. We have considered the effect of repeated venepunctures in terms of haemoglobin loss for the analyses made in the biochemical control of this group. As there is no record of the amounts of blood taken each time, we have estimated the minimum amounts used in carrying out the various tests made, regardless of all wastage, during the treatment period up to the time of the development of anaemia. The calculated loss of blood from this cause is equivalent to an average fall in haemoglobin percentage of $5 \cdot 5$ (range 1.5 to $10 \cdot 5$ ). Assuming that the quantity of blood taken from these infants has probably been at least half as much again as the minimum calculated values, then in most instances the anaemia can be explained theoretically by this blood loss and the increased weight and blood volumes in the absence of adequate absorption of iron. However, not all the anaemia noted in this series was significantly hypochromic. Infections were common in the group and may have accounted for some of the anaemia. The subject seems to warrant more detailed study. Whatever the cause it appears important that the possibility of an anaemia developing during treatment should be appreciated. Its prevention and correction in patients with infantile renal acidosis may have added importance since anaemia is believed to cause impaired renal function (Bull, Joekes and Lowe, 1949).

The aetiology remains obscure. By many the disorder has been regarded as congenital (Greenspan, 1949) and this view is supported by the finding of nephrocalcinosis in siblings (Engel, 1951) and renal acidosis in twins (Rendle-Short, 1953). No such familial incidence has been reported by others. A possible explanation of this occurrence among close relations, especially in early life, may be that they are exposed to similar environmental hazards. Payne (1953) has suggested that the error lies in the differing rates of maturation of the glomerular and tubular functions in the kidney of the young infant. The fact that these children appear perfectly well for the first few months of life and that they seem 
to make a complete recovery if tided over the active stage of the disorder appears to support the theory of an acquired lesion. A number of previously reported cases as well as many of our own have shown traces of albumin and an excess of white cells in the urine with negative cultures. These findings suggest the possibility of a toxic or degenerative renal lesion. Among the patients reported here and elsewhere in the literature with but one exception (Case No. 2, Butler et al.) none have been fully breast fed at the time of onset of the disorder and most were artificially fed after the first two or three weeks of life. This suggested to us the possibility that some ingredient of the artificial feed might be responsible, or alternatively that such things as gripe-water, laxatives, or sedatives given to bottle-fed babies because of their greater predisposition to gastro-intestinal upsets were in some obscure way 'nephrotoxic'.

Our quest for possible extrinsic causal factors, the results of which are summarized in the text and in Tables 5 and 6, does not appear to have yielded any positive information. There was no tendency for figures for blood urea and calcium to be higher in those who had been given the alkali 'magnesia' at home. Moreover, from Table 2 it can be seen that where those values were abnormally high initially, they usually fell to normal on citrate therapy, and remained normal despite heavy and prolonged dosage with that alkali. In this series of cases of infantile renal acidosis, therefore, we have found no evidence that previous medication with 'magnesia' or other preparation is aetiologically related, nor did heavy dosage with citrate result in demonstrable impairment of renal function, either during treatment or many months after such treatment had been discontinued.

\section{Summary}

Seventeen children with idiopathic infantile renal acidosis were diagnosed in the Children's Hospital, Birmingham, during the five-year period 1948 to 1953. The clinical features they presented were in accordance with those previously described.

Alkali in high dosage was used in their treatment but did not give any better results than have been reported with more moderate dosage. Anaemia, which was often hypochromic, developed under treatment with alkali in some. Its possible aetiology is discussed.

Biochemical studies suggest that idiopathic infantile renal acidosis may at times be associated with azotaemia and hypercalcaemia. Aminoaciduria was recorded in only one case.

The follow-up of 13 children whose treatment had been discontinued for periods of from four months to four and a half years suggests that among survivors the disorder leaves no serious ill effect.

A search for extrinsic factors that might cause or precipitate the disease was unfruitful. Prolonged medication with milk of magnesia could not be incriminated.

It is a pleasure to record our appreciation of the help given to us in this work. We are indebted to the physicians of the Birmingham Children's Hospital for permission to study and record their cases, to the nursing staff of the hospital for their invaluable assistance, to Dr. H. Baar for reports on nephrocalcinosis, to Dr. R. Astley for the radiological data, to Dr. H. Bickel for the work on paper chromatography, to Miss E. M. Hickmans for other biochemical data, to Mr. J. G. Williamson for the figures and to Miss J. A. Brennan and Miss M. A. Hollyhoke for secretarial assistance.

\section{REFERENCES}

Bickel, H. and Hickmans, E. M. (1952). Acta paediat., Uppsala, 42, Supp. 90, p. 147.

Smallwood, W. C., Smellie, J. M. and Hickmans, E. M. (1952). lbid., 42, Supp. 90, p. 28.

Bull, G. M., Joekes, A. M. and Lowe, K. G. (1949). Lancet, 2, 229 Butler, A. M., Wilson, J. L. and Farber, S. (1936). J. Pediat., 8, 489. Creery, R. D. G. (1953). Lancet, $2,17$.

Doxiadis, S. A. (1952). Archives of Disease in Childhood, 27, 409.

Engel, W. J. (1951). J. Amer. med. Ass., 145, 288.

Greenspan, E. M. (1949). Arch. intern. Med., 83, 271.

Hartmann, A. F. (1939). Ann. intern. Med., 13, 940.

Hutchison, J. H. and MacDonald, A. M. (1951). Acta paediat., Uppsala, 40, 371 .

Kellogg, F. and Mettier, S. R. (1936). Arch. intern. Med., 58, 278.

Kelsey, W. M., Reinhart, J. B. and Fishel, J. (1950). Paediatrics, 5,689

Latner, A. L. and Burnard, E. D. (1950). Quart. J. Med., n.s. 19, 285. Lightwood, R. (1935). Archives of Disease in Childhood, 10, 205.

- and Stapleton, T. (1953). Lancet, 2, 255.

Mettier, S. R. and Minot, G. R. (1931). Amer. J. med. Sci., 181, 25.

Payne, W. W. (1953). Medical Annual, p. 366.

and Lightwood, R. (1952). Archives of Disease in Childhood, 27, 302.

Rendle-Short, J. (1953). Archives of Disease in Childhood, 28, 55.

Stapleton, T., (1949). Lancet, 1. 683. 